\title{
LESSIUS AND THE BREAKDOWN OF THE SCHOLASTIC PARADIGM
}

\author{
BY \\ WIM DECOCK
}

\section{INTRODUCTION}

Ever since Joseph Schumpeter's appraisal of scholasticism as the breeding ground of modern economic thought, with its normative natural law philosophy presupposing an analytical process in which market activities are carefully scrutinized, ${ }^{2}$ historians of economic thought have increasingly embarked on a journey to unearth the hidden treasures of this almost forgotten realm of thought. The success such an enterprise kept in store had already been made evident in the discovery of the quantity theory of money and the purchasing-power-parity theory by Marjorie Grice Hutchinson in the teachings of the so-called School of Salamanca, which was also said to have been prefiguring the utility-based price theory of the Austrians. ${ }^{3}$ However, if only because there is a lack of mathematical models and growth theories in the work of the scholastics, historians of economic thought also became aware of the need to get back to the basic moral and anthropological assumptions, different from ours, underlying their observations of the economy.

This praiseworthy turn towards contextualization has led scholars to conceive of the economic reflections of the scholastics as belonging to a separate "paradigm," of which a non-exhaustive list of distinguishing features might include the following: (1) market relations are personal and morally ruled by the virtues of charity and justice; (2) intention matters, and one cannot account for a deed by appealing to impersonal

\footnotetext{
${ }^{1}$ Wim Decock (1983) studied Classical Philology at the University of Leuven. Under the supervision of Toon Van Houdt, he wrote his master's thesis about Lessius' views of just pricing and the market, which culminated in the publication of the book Leonardus Lessius: Traditie en Vernieuwing (Antwerpen, 2005). As a Marie Curie Fellow, he currently stays at various research institutes throughout Europe to prepare a doctoral dissertation on the synthesis of law, ethics, and economics in late scholasticism. He would like to thank the participants to the Research Day of the Dutch-Flemish Society for the History of Economic Thought (Middelburg, 2006), two anonymous referees of the JHET, and Prof. Dr. Toon Van Houdt and Prof. Dr. Jan Hallebeek for their useful comments on a draft version of this paper. He is also indebted to the Acton Institute (Grand Rapids, MI, USA) for granting him a "Centesimus Annus Fellowship" to continue his research on Lessius' economic thought. The English of this paper benefited from the corrections made by Dr. Mark Godfrey. Comments are very welcome to wim.decock@inbox.com.

${ }^{2}$ Schumpeter 1972 [=1954], p. 111.

${ }^{3}$ Grice-Hutchinson 1952, pp. 40-58.
} 
market forces; and (3) merchants have a sense of duty towards other merchants and the community as a whole. ${ }^{4}$ All this makes up for a charity-based anthropology underlying scholastic economic thought, wonderfully depicted by Bartolomé Clavero in his Antidora. Antropología católica de la economía moderna-a book Marcel Hénaff recently proposed to rebaptize The Catholic Ethic and the Spirit of Non Capitalism. ${ }^{5}$ That is, following in Max Weber's footsteps, Hénaff believes it precisely to be the "ethic of fraternity" just described which impeded capitalism, and hence modernity, from breaking free. ${ }^{6}$ For that wealth-creating and blessed liberation to happen, the world had to wait for Protestantism, whether or not combined with a dissolution of the just pricing doctrine through a rebirth of genuine Roman sales law. ${ }^{7}$

Yet as primary sources of (late) scholastic literature are brought back to the surface and studied afresh, there are some flaws appearing in this traditional picture of the history of economic thought. Of late, Odd Inge Langholm has demonstrated that at the end of its existence, scholasticism destroyed itself through increasingly giving way to businessmen orienting their behavior towards impersonal market forces which gave them power over other market participants - a breakdown which, according to Langholm, is best seen in the work On Justice and Right De iustitia et iure of Leonardus Lessius, a Jesuit moral theologian who lived in the Spanish-ruled Southern Netherlands at the turn of the seventeenth century (1554-1623). ${ }^{8}$ It should be recalled that this man is rightly credited with having formulated and accepted in an unprecedented way the extrinsic title "lack of money" (carentia pecuniae) for asking interest in a loan for consumption, thereby undermining traditional scholastic teaching on interest and usury. ${ }^{9}$ The disruptive character of Lessius' thought will be brought further to light in this article, as we find him rewarding the prudent businessman playing on the impersonal mechanisms at work in the market.

To that end, I will focus on Lessius' discussion of the licitness of making profit on the basis of a comparative information advantage regarding future market conditions. Although this is a distinctly moral problem, it will be seen that Lessius came to give unusually strong approval to profit-making on the basis of unequally distributed information in the market, because of his recognition that the market is governed by laws of its own-an insight which provides the necessary step towards later, scientifically independent examinations of market processes. ${ }^{10}$ Since the late scholastics dealt with this problem in their elaborations of a case of conscience stemming from Antiquity and known as "The Merchant of Rhodes," in the first part of the paper I will elaborate on this case and the way in which Cicero, Lessius, and other late scholastics dealt with it. From this comparison, after a brief sketch of the

\footnotetext{
${ }^{4}$ See, for example, the various and fundamental contributions of Francisco Gomez Camacho and the recent article by Oscar De-Juan and Fabio Monsalve 2006.

${ }^{5}$ Hénaff 2003, p. 296.

${ }^{6}$ Hénaff 2003, p. 322.

${ }^{7}$ The latter point is made by Whitman 1996, pp. 1867-1871.

${ }^{8}$ Langholm 1998, p. 98. For an overview of the life, times, and economic ideas of Leonardus Lessius, see the manual edited by Bertram Schefold 1999. Recently, a revised biography was included in Van Houdt and Decock 2005, pp. 11-54.

${ }^{9}$ See, for example, Noonan 1957, pp. 351-352; Weber 1959, pp. 154-156; De Roover 1969, p. 21; Gordon 1975, p. 250; Beutels 1987, pp. 42-48; and Van Houdt 1998c.

${ }^{10}$ Schumpeter 1972 [1954], p. 107.
} 
adaptations the case underwent in early modern Protestant traditions, the peculiarities of Lessius' thought will emerge. Before finally trying to pin down some factors explaining Lessius' idiosyncratic views, I will produce further evidence of his testing the boundaries of what is generally conceived of as the scholastic paradigm in economic thought.

\section{“THE MERCHANT OF RHODES" FROM CICERO TO LESSIUS}

The information problem was tackled by the scholastics in their reflections on "The Merchant of Rhodes,' a case of conscience they borrowed through Thomas Aquinas' Summa Theologiae from Cicero's De officiis, a work on moral philosophy which experienced a remarkable revival in medieval and early modern times. ${ }^{11}$ The story goes as follows. A decent merchant (vir bonus et sapiens) is shipping grain from Alexandria to the island of Rhodes, where prices have raced up and people are dying from starvation (in Rhodiorum inopia et fame). At the same time, he knows for sure that many more grain dealers are setting forth to Rhodes, and will be arriving there in the near future. The qualm of conscience he faces is whether or not he is obliged to tell the wretched citizenry of the boost in supply coming soon, thereby giving up on making huge profits. It should be noted that Cicero explicitly confronts us with a seller who is distinctly sincere and who wonders if it is in accordance with the principles of decency (honestas) to conceal his information to buyers who, in their turn, are explicitly said to be in a desperate position. ${ }^{12}$

Put differently, Cicero's account pays a lot of attention to the personal conditions of the parties involved, and, what's more, it is set against the background of his larger, typically Stoic discussion of the wrongfully perceived antithesis between the good (honestum) and the useful (utile). Cicero tackles the problem of the merchant of Rhodes in an attempt to show that it is a mistake to believe that dishonesty and morally irresponsible behavior are the necessary prerequisites for material success. For, as the Latin word for moral decency (honestas) as opposed to moral depravity (turpitudo) itself suggests, honesty leads to honor (honor), which is the very linchpin of utility (utilitas). So even if he is aiming at usefulness, the merchant of Rhodes should not think that he will be better off by concealing his information.

Lessius and the late scholastics, however, put "The Merchant of Rhodes" in a different context, namely their more technical theory of pricing and of justice in

\footnotetext{
${ }^{11}$ The importance of early modern elaborations on passages from Cicero's De Officiis for the development of economic thought has been highlighted by Vivenza 2001, pp. 201-227 and Vivenza 2004, pp. 507-523. As to adaptations of the Ciceronian case in 17th-century humanism, see my discussion of Caspar Barlaeus' (1584-1648) speech On the Merchant Philosopher in Decock 2006, pp. 248-250.

${ }^{12}$ Cicero, De officiis 3, 12, 50. In: Cicéron, Les devoirs. Livres II et III. Texte établi et traduit par Maurice Testard, Collection des Universités de France, Paris, 1970, p. 96: 'Si exempli gratia vir bonus Alexandrea Rhodum magnum frumenti numerum advexerit in Rhodiorum inopia et fame summaque annonae caritate, si idem sciat complures mercatores Alexandrea solvisse navesque in cursu frumento onustas petentes Rhodum viderit, dicturusne sit id Rhodiis an silentio suum quam plurimo venditurus? Sapientem et bonum virum fingimus; de eius deliberatione et consultatione quaerimus, qui celaturus Rhodios non sit si id turpe iudicet, sed dubitet an turpe non sit.'
} 
economic exchange (iustitia commutativa), and they abstract from a concrete description of the personal conditions the buyer and seller are in:

Is it allowed to sell a good at the current price (pretium currens), even though one knows for sure that the price of that good will soon be plummeting? For example, one disposes of the information that a big mass of goods will be imported from elsewhere, or that a stock which had been hidden thus far, will be brought to the market. Can one conceal those facts, and simply ask the current price (pretium usitatum)?" 13

Since the late scholastics are approaching the case of "The Merchant of Rhodes" from a particularly objective point of view, focusing on prices rather than on the personal conditions of buyer and seller, the solution of this moral question will naturally follow from their general doctrine of the just price (pretium iustum), which aims at preserving the equality between what is given and received in an exchange (aequalitas). All in all, "The Merchant of Rhodes" raises the question as to what extent expectations and knowledge about future events should determine the just price-making process at present. ${ }^{14}$ In the eyes of the theologians, this merchant is like a Hercules standing at the crossroads. Either he decides to sell his goods at the highly profitable current price, not letting his personal expectations have any influence on the making of the price, or he anticipates the sunken future price, thereby giving the greater weight to his personal knowledge, and, last but not least, doing bad business. Ultimately, the dilemma the merchant is facing amounts to the bigger question of whose knowledge should prevail in a just price-making process: the information of the individual, or the knowledge of the larger community.

\section{TWO DIRECTIONS IN LATE SCHOLASTIC ADVICE TO "THE MERCHANT OF RHODES"}

Is it licit for a businessman to silently stick to the current price, based on common estimation, or should he shoulder responsibility for the community and adapt, i.e., cut prices according to his personal knowledge of the future market conditions? Depending on how the late scholastic theologians answer this question, they might be subdivided into two schools of thought. ${ }^{15}$ Among those who, in some cases at least, give personal knowledge priority over the information possessed by the community, are Conradus Summenhart (1458-1502) and Ioannes Medina (1490-1546). Following the lead of Thomas Aquinas, the luminaries of the opposite direction are Ludovicus Molina (1535-1600) and Leonardus Lessius (1554-1623), a Jesuit duo which, it is worth mentioning, belonged to a younger generation of scholars. In the following

\footnotetext{
${ }^{13}$ Lessius, De iustitia et iure 2, 21, 5, 38. A translation of the most important discussions from the point of view of the history of economics in Lessius' chapter on buying and selling is included in Decock 2007, pp. 463-516.

${ }^{14}$ Gómez Camacho 1981, p. 77.

${ }^{15}$ For the sake of brevity, an exhaustive list of all late scholastic, let alone medieval jurists and theologians who elaborated on "The Merchant of Rhodes" is not included here. This paper focuses on the arsenal of pro- and counter-arguments surrounding "The Merchant of Rhodes," all of which were most adequately debated in the works of the authors quoted.
} 
paragraphs, I would like to summarize their respective ideas on "The Merchant of Rhodes." To avoid any misinterpretation, one should keep in mind that both schools of thought endorse the view that a just price, unless it is set by the authorities, is determined by common estimation (communis aestimatio). Yet while the former theologians think that the common estimation requires some qualification, for instance in case of asymmetrical information, the latter hold on to a very rigorous application of the principle of common estimation.

Ioannes Medina, a famous professor of nominalist theology at the University of Alcalá de Henares, answered the question of "The Merchant of Rhodes" plainly in the negative. ${ }^{16}$ A merchant is not allowed to sell at the current price when he knows of a different price in the near future. Since he knows that the common estimation stems from false assumptions and a lack of information, he cannot in fairness decide to ask the current price based on it. ${ }^{17}$ The essence of Medina's reasoning is that a seller is obliged to let the buyer know of his personal information, because otherwise voluntary consent to the contract is jeopardized: the price the buyer agrees to is not the just price, but the price he mistakenly thinks to be the just price. Like the Roman philosopher Cicero back in the first century B.C., Medina urges the merchant to tell the other party explicitly about changes in circumstances affecting both the internal and external qualities of the merchandise. Buyers consenting to the high, current price are only doing that for lack of knowledge, they are not consenting voluntarily. In a more transparent situation where knowledge is equally distributed, they would never have agreed to the price set in the contract.

In sum, Medina maintains that for a contract to be licit, not only should there be a fair ratio of money to commodities, guaranteed by the just price, but also a balanced relation between buyer and seller: their "conditions" should be equal. ${ }^{18}$ Moreover, he argues, a not too distant arrival of a mass of goods has the same price-lowering effect on the common estimation as a bulk of goods effectively present. "The Merchant of Rhodes," then, should tell the buyer about the future events, and in good conscience anticipate the future price-a viewpoint which, a few decades earlier, the highly influential German thinker Conradus Summenhart had officially subscribed to. Although he had put forward the idea that a merchant is allowed to sell at the current price in order to avoid personal loss, he safely concluded that, in the end, selling at the current price knowing that there is going to be a sharp decrease in the level of prices is acting against the principles of justice. ${ }^{19}$

A few decades later, Molina and Lessius gave an utterly affirmative answer to the problem of "The Merchant of Rhodes"- a daring stand which was perfectly in line with their larger philosophy of just pricing. Following traditional late scholastic economic reasoning, they argued that a just price could be established either by an order of the prince (pretium legitimum), or by the common estimation of prudent men

\footnotetext{
${ }^{16}$ Medina, De poenitentia, restitutione, et contractibus, 2, De rebus restituendis, 35.

${ }^{17}$ Actually, Medina argues that a seller should ask a price only a little bit below the current price, not the collapsed price to be expected in the future. In practice, then, his view is not that different from Lessius' - a fact which makes their disagreement on the speculative level all the more significant.

${ }^{18}$ Medina, l.c.: "deberet ipsorum contrahentium conditio aequalis esse."

${ }^{19}$ Summenhart, De contractibus, 3, 62-3.
} 
(pretium naturale) ${ }^{20}$ Regardless of the way in which it was set, in order to be regarded as just, a price had to amount to the equal price (pretium aequale), which secures a just or equal relationship between price and commodity. For this to happen, a price should reflect a series of factors (circumstantiae) determining the value of a good, to be commonly estimated by all experienced and intelligent men (prudentes) present in the market-not by a single person. A very concise, yet illuminating account of these circumstances is delivered to us by Lessius. ${ }^{21}$ At the level of the objects of the salepurchase contract, what matters is the abundance or scarcity of the goods offered, their power to satisfy public or private needs, and the amount of money available. What counts at the personal level is the number of buyers and sellers, the usual labor, expenses, and risks the seller faces in obtaining the goods and bringing them to the market, and, last but not least, the way in which buyer and seller interact. ${ }^{22}$

Unlike their predecessors, Molina and, a fortiori, Lessius logically applied this general theory of the just or equal price to the case of "The Merchant of Rhodes." Since a just price depends on a common estimation (communis aestimatio) of some relevant factors, the knowledge and estimation of a particular individual should, by definition, not determine the just price. So conceived, "The Merchant of Rhodes" is fully allowed to ask the current price based on the common estimation of all prudent, yet badly informed people in the market. After all, the private knowledge of a seller affects the common sense and estimation of all market participants just as little as the private information of any single buyer. The common estimation thrusts itself upon all market participants, no matter what their personal condition or knowledge looks like-a seemingly harsh conclusion restated by Lessius even more strongly later on in his discussion of buying and selling:

The one who sells at the current price, knowing that a bulk of goods will soon arrive in the market, does not commit a sin against justice (see problem 5 [i.e. "The Merchant of Rhodes"]), despite the fact that the [common] estimation is based on error and ignorance. ${ }^{23}$

Apparently, Lessius is not prepared anymore to attach even the slightest importance to personal factors in a sale-purchase deal: even before the court of conscience, a merchant merely has to observe the rules of commutative justice in order to be "safe." For Lessius, from now on, the key to solving moral problems should be sought and found in the mere, objective equality between price and commodity, guaranteed by the just price, set either by the authorities or the common estimation of prudent men.

\footnotetext{
${ }^{20}$ Lessius, De iustitia et iure 2, 21, 2 and Molina, De iustitia et iure 2, 347-8.

${ }^{21}$ De iustitia et iure 2, 21, 2,8.

${ }^{22}$ From this account, it becomes clear that any attempt to bring Lessius' economic thought under the headings of either "a utility theory of value" or "a labor theory of value" fails to do justice to his sharp and remarkably balanced analysis of the price-making process. It should be noted, by the way, that much of the "labor versus utility" polemic was sadly provoked by an ambiguous 13th-century translation of the Greek word "chreia" ("need") with the Latin word "opus" (which means both "need" and "work") before it was fully exploited in the ideological war during the cold second half of the 20th century (Langholm 1979, pp. 75-9). A very critical and sound survey of the history and the contemporary interpretations of just pricing theories in pre-modern economics is offered in Hamouda-Price 1997.

${ }^{23}$ De iustitia et iure 2, 21, 10, 80 .
} 


\section{SELF-INTEREST, LYING, AND CHARITY}

Dismayed at this pretty straightforward reasoning by a respectable Jesuit, one might raise the following objection. Although it is licit-that is, not against justice-to cash in on a dominant knowledge position, charity might be nevertheless offended by such an act. Should we not expect a really honorable and Christian businessman to share his information about external circumstances with the other party to the contract? ${ }^{24}$ Not surprisingly, it seems as though Lessius himself had expected this objection. Immediately after he has settled the question of "The Merchant of Rhodes," he tells his reader not to misunderstand his bold conclusion: it is, indeed, the result of a reasoning merely based on justice.

However, it has to be said that Lessius' concession seems far from convincing. First of all, making the assumption that a merchant should behave in a charitable or liberal way is to commit a category mistake. In the business of buying and selling, gifts are simply not to be expected. What is more, they ought to raise suspicion, unless the two parties are closely affiliated with each other by family bonds or ties of friendship:

For donation is never to be assumed to take place under people who do not know each other, unless there are crystal clear signs of a willingness to make a gift. ${ }^{25}$

This is to do, amongst other reasons, with the paralyzing inflation of scrupulosity from late medieval times onwards, which Jesuits like Lessius wanted to control by minimizing the moral rules which merchants had to observe, even before the inner court of conscience in which the merchant faces God through the mediation of a confessor. ${ }^{26}$ Though in preaching from the pulpit, or in writing spiritual literature, a priest had to make his flock aspire to celestial perfection, in the hearing of confession he had to judge conscience as a mild Father acting in accordance with much more practicable principles as included in case books such as Lessius' $D e$ iustitia et iure. If not, the faithful would get frustrated, defeatist, and perhaps even stop trying to live as Christians in everyday life altogether:

It is safer to assume that no binding precept exists altogether, since it is dangerous to overload conscience with unnecessary precepts.... Consequently, it is better for the penitent to know that he is not bound. In this manner, he will not sin if he does not

\footnotetext{
${ }^{24}$ This was the clear view of, for example, Thomas Aquinas with regard to information a buyer or seller has concerning the substance, quantity, or quality of the merchandise subject to the exchange (see Lapidus 1994). However, in Lessius' thought one should make a distinction between information regarding the merchandise on the one hand, and unequally distributed knowledge about external market circumstances on the other, because of the juridical concepts underlying his moral problem solving method; see p. 71, "The drastic juridical turn in Lessius' economic ethics."

${ }^{25}$ De iustitia et iure 2, 21, 4, 37. Further evidence of this rule is to be found in 2, 21, 3, 18 and 2, 21, 11, 84. A similar sharp distinction between donation and sale-purchase is made by Pufendorf; see below "After Lessius. Catholic and Protestant traditions."

${ }^{26}$ Van Houdt 1998d, pp. 30-31. Consequently, it would be inappropriate for us to read modern theories about justice and charity into Lessius' text. Nowadays, minimal rules of justice are supposed to apply before the (secularized) external tribunal, while intention and charity constitute the measures of the (Christian) court of conscience. For reasons of space, we cannot afford to elaborate on Lessius' moral theory; an outstanding introduction is to be found in Stone and Van Houdt 1999.
} 
observe the precept, and accomplish an act of supererogation if eventually he still does. I admit, though, that in the case mentioned it is safer to observe the precept. It does not follow from this, however, that it is necessary to do that. Otherwise all people ought to obey the counsels of Christ, for that would be the safest way. But this would mean that everybody is obliged to lead a life devoted to God and to abstain from business. ${ }^{27}$

In addition, requiring those rather splendid attitudes of Christian merchants would end up being counter-productive. For, as Langholm has stated, "preaching charity as a general norm of market conduct would reach only those who desired to be virtuous, and the end effect would be an accumulation of wealth in the hands of the vicious." 28 It is precisely this argument which Lessius put forward to defend Christian bankers and businessmen who seemingly committed usury in taking part in the moneyexchanging activities at the Frankfurt Bourse:

These money-exchanging practices ought not to be condemned, particularly since they are the common practice at all marketplaces and many virtuous and scrupulous merchants participate in them. Now if the latter were told to withdraw from these affairs, the wicked would introduce even more unbridled banking business. ${ }^{29}$

Last but not least, Lessius himself promptly adds that regularly (regulariter) selling at the current price knowing that there is going to be a sharp drop in prices does not even go against charity. Only if the buyer would be ruined, would it be illicit to sell at the current price. For, in Lessius' view, charity itself does not oblige us to abandon our self-interest, even if that would be required to salvage our neighbor from an equally high loss. The one who, nevertheless, forgoes profit, in this manner accomplishes a work of supererogation:

As a rule, however, it does not go against charity, since it is allowed to stand up for yourself even though as a result your neighbour will suffer an equally serious damage. This is clearly indicated by Thomas' statement that a seller is endowed with ample virtue if he lowers the price or communicates his knowledge about the future times of plenty. ${ }^{30}$

But, what, according to Lessius, is the limit to self-interest? Officially, in On Justice and Right he proclaims that taking care of one's own interest should stop where fraud and lying begin. ${ }^{31}$ In practice, however, he takes a much more relaxed position, as can easily be seen from his discussion of a case of conscience quite similar to "The Merchant of Rhodes," in which one businessman (A) is questioned by another (B). The question is whether person (A) is obliged to unveil his private knowledge of the price level in another province, if otherwise businessman (B) will suffer great damage. ${ }^{32}$ Lessius approves of a merchant who is loath to reveal his

\footnotetext{
${ }^{27}$ See Lessius, De beatitudine et actibus humanis praelectiones theologicae posthumae 19, 44.

${ }^{28}$ Langholm 1998, pp. 155-156.

${ }^{29}$ De iustitia et iure 2, 23, 6, 57.

${ }^{30}$ De iustitia et iure 2, 21, 5, 43. Compare with 2, 20, 19, 168.

${ }^{31}$ De iustitia et iure 2, 21, 5, 43.

${ }^{32}$ See Lessius, Variorum casuum conscientiae resolutiones, s.v. Contractus, 9, 16. casu IX, numero 16. This case was included in an anthology of cases of conscience Lessius had solved during his career as a moral advisor. It was posthumously published by his nephew Iacobus Wijns SJ.
} 
personal information, simply because by doing that he would suffer a loss himself - in which case he is allowed to avail himself of a white lie (mendacium officiosum) ${ }^{33}$ Yet, what is more, Lessius even explicitly allows businessman (A) to intentionally give a false answer to businessman (B), although the latter will, thereby, incur great damage:

I reply that in the following case a business man does not seem to be bound to make restitution: $\mathrm{He}$ is asked about the price level of grain in a certain province, and maintains that prices are lower in that place and that there are plenty of grain reserves available there, in order to prevent the other businessman from bringing his stock to that market, whereby his own grain stock would suddenly drop in value. For, it is common practice among businessmen not to tell the truth in such a case, since they would suffer damage as a result of that. ${ }^{34}$

So, within the boundaries of business practice, our author even approves of a wholly pernicious lie (mendacium perniciosum), arguing that it is just the way of daily business practice to use information as a private weapon for making money-a controversial position indeed, if only because in his treatise On Justice and Right, Lessius does not dare to take such a stand except indirectly by pointing to the views of "some" (quidam). ${ }^{35}$ On closer examination, however, it turns out that "some" actually refers to just one single person, namely Petrus Aragonensis (1545-1592). Actually, on both formal and intrinsic grounds, one cannot escape the impression that Lessius' treatment of "The Merchant of Rhodes" as a whole in On Justice and Right was modelled on Aragonensis' discussion. ${ }^{36}$ A professor of logic at the University of Salamanca, the latter displays a rational approach to sale-purchase from an "objective" point of view quite similar to that of Molina and Lessius. Paying attention only to the equality between the objects of the contract (price and good), while abstracting from personal factors (knowledge and speech), Aragonensis too belongs to a younger generation of late scholastic moral philosophers.

\section{INSIDER TRADING}

Thus far, Lessius' overall assessment of asymmetrically distributed information is on a par with that of his contemporary Ludovicus Molina. If, for instance, a merchant knows that soon there will be a huge boost to the supply of his merchandise, he is allowed to sell the number of goods he had intended to sell at the current price, and, on top of this, as many more of them as he wishes-for that is a matter of business acumen. There is, however, a point at which our Flemish Jesuit goes beyond the limits set by this most typical exponent of the younger generation of late scholastic economists.

\footnotetext{
${ }^{33}$ De iustitia et iure 2, 21, 5, 43 : "Si tamen ipse rogatus, an non expectentur naves vel an non sit futura maior copia, diceret se nescire. Putarem non teneri ad restitutionem, quia non tenetur veritatem aperire cum tanto suo incommodo."

${ }^{34}$ Variorum casuum conscientiae resolutiones, s.v. Contractus, 9, 16. casu IX, numero 16.

${ }^{35}$ De iustitia et iure 2, 21, 5, 43: "Imo quidam putant non teneri, etiamsi diceret non fore copiam. Hoc enim mendacium censeri officiosum ad vitandum damnum proprium. . . Ita Petrus Arragon q. 77, art. 3."

${ }^{36}$ Aragonensis, De iustitia et iure, 77, 3.
} 
Consider the following case. Through industry and personal contacts, a merchant is informed by a civil servant that soon a decree will be promulgated setting a ceiling to the grain price. Is it licit for this businessman to make extra profits on the basis of this knowledge? The real crux behind this case is that in traditional scholastic thought there is an essential distinction to be made between information that should be imparted to all members of the community, on the one hand, and information which it is licit to possess as an individual, on the other. According to Molina, knowledge of a decree or law is a typical example of information that should be known commonly, and, as such, should not be a source of personal enrichment:

If you take advantage of the knowledge of a law that has not yet been promulgated to enrich yourself at the cost of others, then you appropriate yourself to the detriment of others of the knowledge of a thing which should be commonly known, and therefore you wrong other people. However, if to the same ends you take advantage of your knowledge about an imminent abundancy of merchandise, you do not appropriate yourself of the knowledge of a thing which should be commonly known, but rather enjoy the fruits of your industry, professional skills and good luck. ${ }^{37}$

So if someone avails himself of a law not yet publicly promulgated in order to sell more (plus) than he had intended originally, he commits a deed he was not entitled to commit. If, on the contrary, the merchant limits himself to selling the amount of goods he initially meant to bring on the market, he can safely ask the current price. This is because he should not be injured by knowing a law ahead of the rest of the people either.

Now Lessius abandons this traditional line of reasoning. He simply ignores the distinction made between different types of knowledge on the grounds of their object, and plainly states that it is licit to put a surplus on the market merely on the grounds of private knowledge of a law not yet publicly promulgated. This rule applies, even if others will suffer damage from a merchant's private use of information which should be shared by all members of the community. For, unlike a civil servant, a citizen is not expected nor obliged to promote the benefit of others. And since it is licit for a card player to raise stakes on seeing that he has a good hand, similarly, a businessman is in any case allowed to sell a surplus when fortune smiles upon him. Let us consider the remarkable arguments Lessius puts forward to defend his view:

(1) A law forbidding me to avail myself of this decree does not exist.

(2) Whether I am selling because of the knowledge of that decree, or for another reason, does not affect at all the equality or inequality ultimately to be preserved in a contract.

(3) The interior intention cannot turn an exterior act, just in itself, into an unjust deed that would require restitution. ${ }^{38}$

On account of this argumentation, one may wonder what remains in Lessius of the traditional picture of that intellectual paradise known as the scholastic paradigm in

\footnotetext{
${ }^{37}$ Molina, De iustitia et iure 2, 354, 4.

${ }^{38}$ Lessius, De iustitia et iure 2, 21, 5, 46-47.
} 
economic thought. ${ }^{39}$ Although it may sound like a paradox, after the attack launched on the late scholastic empire by Lessius" "Merchant of Rhodes," from now on evangelical charity, inner intention, and the ethics of fraternity might well have taken refuge outside of it, perhaps in the extreme Protestant community.

\section{AFTER LESSIUS: CATHOLIC AND PROTESTANT TRADITIONS}

In addition to the observed lack of consideration for inner intentions in a distinctly impersonal market, the idea that charity does not oblige us to abandon our selfinterest, even if that would be required to salvage our neighbor from an equally high loss, remains striking. Nevertheless, through Lessius, amongst others, this very conception gained solid ground in the later catholic moral theological tradition. Its revered patron and doctor of the Church, Saint Alphonsus de Ligorio (1696-1787), settled the "charity question" regarding the "The Merchant of Rhodes" for centuries to come in his monumental Moral Theology. By making reference to Lessius in the first place, and in refuting Constantinus Roncaglia's (1677-1737) more reserved approval of "The Merchant of Rhodes," Saint Ligorio authoritatively declared: (1) a merchant looking after his self-interest without harming the principles of justice is merely exercising his right (utitur jure suo) and not acting against charity, even though his neighbor suffers consequential damage; (2) he is not bound by virtue of charity to reveal his knowledge to a colleague if that causes him any inconvenience (incommodum). ${ }^{40}$

In the meantime, Protestant natural lawyers like Hugo Grotius (1583-1645) and Samuel Pufendorf (1632-1694) had also touched upon "The Merchant of Rhodes."41 Explicitly referring to the late scholastics and the medieval legal tradition, Grotius made a distinction between precontractual duties to inform about defects in the merchandise on the one hand and knowledge about circumstances external to the good itself on the other-a distinction later also adopted by Pufendorf. Continuing the "rights-talk" of the late scholastics, he did not think it to be necessary, according to the principles of justice, that a seller communicate his knowledge in the latter case. For not communicating his knowledge would infringe nobody's right. Sadly, Grotius only briefly suggests that the behavior of "The Merchant of Rhodes" often goes against the rule of charity, without further clarifying his statement. It seems as though Grotius would have taken a tougher stand on this than, say, Ligorio. Pufendorf, on the other hand, clearly does take a position as to the charity point of view, which, characteristically, he rebaptizes as "the law of beneficence and humanity" (lex beneficentiae et humanitatis).

According to Pufendorf, there are three main reasons ruling out, from the point of view of the law of humanity, that the merchant of Rhodes be obliged to communicate his knowledge. First, in order for an obligation stemming from the law of humanity to

\footnotetext{
${ }^{39}$ The traditional portrait of scholastic economic thought as depicted by some contemporary scholars is sketched in the "Introduction."

${ }^{40}$ Alphonsus de Liguori, Theologia moralis 3, 5, 3, 8, 1, 824, 12.

${ }^{41}$ See Hugo Grotius, De jure belli ac pacis 2, 12, 9, and Samuel Pufendorf, De jure naturae et gentium 5 , 3, 4 .
} 
emerge, it is necessary that another person is really in need of beneficence. Now the latter is obviously not the case with "The Merchant of Rhodes," because from Antiquity onwards the inhabitants of Rhodes are renowned for being rich. So though they might be in need of grain, they are certainly not in need of money or any other beneficence. Secondly, in an almost Kaldor-Hicksian mode of arguing, Pufendorf has it that a duty of beneficence cannot arise if by telling the truth one incurs a cost which exceeds the benefit falling to the other party. Now if the merchant of Rhodes reveals his information, the decrease he alone suffers in his profits will exceed the increase in gain for a plurality of buyers. His third and last argument recalls Lessius' sharply drawn distinction between the logic of the market and the logic of gift: usual business practice does not mean to be beneficent.

However clear the position of Pufendorf, another Protestant writer, the English Puritan Guilielmus Amesius (1576-1633), was not that convinced about the overall licitness of the behavior of "The Merchant of Rhodes." In his treatise On the law of conscience, a case book highly influential in the Reformed Church which claims itself to be a genuinely Gospel-based counterpart to the corrupted writings of the "papalists," Amesius does not adopt the "rights-talk" of the Catholic late scholastics. ${ }^{42}$ In fact, the lack of a large systematic treatment of the law of contract and property in On the law of conscience marks an important underlying contrast in mentality with the highly juridical treatises On Justice and Right of the Catholic casuists. Amesius does not maintain the "rights-talk" which allows a merchant always to exercise his own rights in a just way, but simply believes charity to imply a continuous duty to care for the well-being of one's neighbor. As such, a seller is obliged to indemnify the buyer as soon as the latter suffers gross damage as a result of his behavior. As long as it does not cause great detriment (magnum detrimentum) to himself, "The Merchant of Rhodes" should care for his neighbor.

The Catholic merchant, then, enjoys much more freedom: from the moment he feels that caring for his neighbor could cause any inconvenience to himself, charity allows him first and foremost to look after his own interest. Put differently, the Catholic merchant, guided by Lessius or Ligori, is plainly released from qualms of conscience preventing him from actively participating in the information-gathering and speculation activities so typical of a thriving early capitalist society. The question arises, then, why was Lessius so confident in contributing to this change in worldview? What might explain the way in which Lessius' argumentation paradoxically bears the marks of both the scholastic and liberal paradigms in economic thought? ${ }^{43}$ In what follows it will be argued that the hybrid nature of Lessius' thinking is an inevitable consequence of his methodological strictness in applying the scholastic doctrine of the just price. His almost mathematical consistency was necessitated by the growing depersonalization of the early seventeenth-century marketplace itself for

\footnotetext{
${ }^{42}$ Guilielmus Amesius, De conscientia et ejus iure 42, 3, 11.

${ }^{43}$ The notion of a "liberal paradigm," in the sense of a paradigm that conceives of the market primarily as a place where individuals fiercely compete with each other for the sake of their own profit, as opposed to the older "just price paradigm," centered around an ethics of fraternity, is borrowed from Gómez Camacho 1981, p. 83. Alternatively, with Baeck 1994 one could speak of the "Atlantic tradition" and the "Mediterranean tradition" in economic thought, respectively. In Decock 2006, pp. 257-260 an attempt has been made to present Lessius as a bridge-figure standing in between these two traditions.
} 
one thing, and by the juridical tools increasingly adapted by moral theology to come to grips with the growing complexities of commerce for another. On top of this, Lessius' particular conception of doing business as a game governed by its own rules further stimulated him to construct a transparent and simple normative framework for business life that would allow an industrious businessman to reap the fruits of his insight into the mechanics of the market.

\section{LESSIUS' RAZOR: THE DOCTRINE OF THE JUST PRICE}

More than anybody else, Lessius consistently relied upon a method in moral problemsolving very typical of scholasticism - a method which proceeds by identifying some basic theoretical principles, and then logically extracting consequences from these principles. With regard to buying and selling, in particular, Lessius claimed this fundamental principle to be the just price (pretium iustum). So conceived, the majority of business ethics were to be incorporated into the wider doctrine of the just price. ${ }^{44}$ The just price, then, aims to preserve equality (aequalitas) between the objects of the salepurchase contract, lest commutative justice (iustitia commutativa) is harmed. ${ }^{45}$ Consequently, the just price is perfectly synonymous with the equal price (pretium aequale). And, in any event, the equal price is objective to all participants in the market, irrespective of their personal condition or knowledge. Molina had already stated that whether a sale-purchase contract is to be deemed licit or not primarily depends on the fairness of the price it contains. ${ }^{46}$ Lessius would have totally agreed with that, except for one thing: he would have replaced the word "primarily" with "exclusively." For, in an unprecedented way, he applied the doctrine of the just price to various cases with the utmost consistency.

In practice, as a criterion determining the righteousness of a deed, the just price is a razor cutting both ways. On the one hand, it leads to conclusions which may be perceived as very permissive and progressive_-such as in the case of "The Merchant of Rhodes." Yet, by the same token, it brings forth surprisingly conservative viewpoints. Consider the case of luxuries, for instance. According to Lessius, a seller is not allowed to ask the highest price he can exact from the buyer for extraordinary goods like exotic birds, antiques, and gems. For, in any case, the just price is not to be set by the arbitrariness of a seller, nor the amount a capricious buyer is willing to pay on the grounds of his personal wishes. ${ }^{47}$ As always, a rational and objective analysis of the relevant market factors should be made by a group of prudent men, or in good faith by the seller himself:

Rather, they should be priced according to the common estimation of knowledgeable men or through the estimation of the seller himself, provided that, in good faith, the latter considers all the relevant circumstances mentioned above. ${ }^{48}$

\footnotetext{
${ }^{44}$ Regarding interest as the market price for money, Lessius took the first step to integrate the doctrine of interest-taking and money-lending within the doctrine of just pricing (Van Houdt 1998a, p. 250).

${ }^{45}$ De iustitia et iure $2,1,2,9$.

${ }^{46}$ Molina, De iustitia et iure 2, 347, 1.

${ }^{47}$ Lessius, De iustitia et iure 2, 21, 3, 19.

${ }^{48}$ Lessius, De iustitia et iure 2, 21, 3, 16.
} 
Traditionally, however, the seller did get the green light to ask any price he could extort from the buyer. The father of Spanish scholasticism, Francisco de Vitoria (1486-1546), made an influential distinction between luxuries and necessaries, allowing the former to fetch any price, since one was not expected to be forced by necessity to consent involuntarily to buying a luxury good at a towering price. ${ }^{49}$ In the case of luxury goods, the traditional protection by the common estimation was not needed, since there was no danger of abusing any need of the buyer. ${ }^{50}$

To sum up, it makes no sense to indict Lessius for moral laxity. Our Jesuit thinker is simply extracting the consequences of the basic principle of the just price, scholastic in nature, which underlies his assessment of morality in business life. ${ }^{51}$ Another remarkable example of this methodological consistency is to be found in his discussion of bonds. ${ }^{52}$ According to traditional teaching, buying a bond at a discount is equal to lending an amount $X$ minus $Y$, in order to receive $X$ after a period of time. Consequently, it is considered to be implicit usury, and, thus, illicit. Lessius, to the contrary, maintains that, since a right to receive money in the future is valued less by common estimation in the marketplace, the just price of a bond is below its nominal value. Furthermore, he crushes the counterargument that common estimation is not prudent for being the result of involuntary consent on the part of sellers who are desperately in need of liquidity. In Lessius' view, necessity is the driving force behind almost all transactions, so it is not a good ground to judge, let alone nullify a contract. As long as sellers of a bond receive the price which it commonly fetches, justice is done. Nevertheless, it seems that, officially at least, Lessius was astonished by his own logical discourse. For in On Justice and Right, as opposed to his case study in the Auctarium, ${ }^{53}$ he safely, yet unconvincingly concludes that it is safer not to buy bonds at a discount. ${ }^{54}$

Interestingly, the procedure whereby Lessius develops a well-founded reasoning following from his theory of the just price, only to refute it at the end of his discussion in a short and utterly unpersuasive manner, repeats itself in a case tying in with the former: is it licit for a businessman to sell his bonds to another person at the current price, knowing that the original debtor has become insolvent? After first having developed a groundbreaking and lengthy argumentation in favor of the

\footnotetext{
${ }^{49}$ On just pricing and luxuries in scholastic economic thought, see Van Houdt 1998a, pp. 311-320.

${ }^{50}$ Lessius summarizes the viewpoint of his opponents in De iustitia et iure 2, 21, 3, 15: "cum non sint necessariae vitae humanae, si quis velit eas emere, sponte censebitur velle dare quod alter exigit (alioquin non emeret, cum nulla necessitas eum ad hoc compellat), quare venditor poterit accipere."

${ }^{51}$ Lessius' innovative acceptance of the extrinsic title "lack of money" (carentia pecuniae) in interesttaking followed from his consistent use of the scholastic problem-solving method too (Van Houdt 1998b, pp. 59-68).

${ }^{52}$ For an in-depth discussion, see Decock 2008, forthcoming.

${ }^{53}$ Variorum casuum conscientiae resolutiones, s.v. Mutuum 3, 3 ("Franciscus mercator dedit Titio 100 ut post mensem ei in assignatione vel chirographo solvat 101"), 9: "Doctores non videntur agnoscere alios titulos [i.e. praeter lucrum cessans et periculum sortis], ratione quorum praesens pecunia pluris possit aestimari quam absens tempore. Puto tamen verum esse posse: non quod praesens pecunia pluris aestimetur quam assignatio, cum plerumque mercatores non nisi per assignationes solvere soleant, sed propter absentiam pecuniae."

${ }^{54}$ De iustitia et iure 2, 21, 8, 73. A deconstruction of the latter passage is included in Decock 2005, pp. 291-302. Lessius' strong and lengthy argument in favor of buying bonds below par led Chafuen 2003, pp. 123-124 to conclude that Lessius generally accepted this practice.
} 
affirmative answer, Lessius quite uncomfortably wriggles out of it, only to sit back and enjoy the traditional standpoint. ${ }^{55}$ However stunning this conduct may be, as well as being a quite usual method in scholasticism for gradually introducing new ideas, it points to a crucial fact, namely the explosive nature of a kind of moral reasoning that merely pays attention to commutative justice. More particularly, it highlights the revolutionary potential of Lessius' wide approval of economic power ensuing from a dominant knowledge position in his discussion of "The Merchant of Rhodes." One of the chief arguments Lessius puts forward in favor of a merchant selling his bonds at the current price is based on analogy-another problem-solving method very typical of scholastic casuistry 56 - with the case of the "The Merchant of Rhodes": since gross ignorance did not invalidate the contract in the latter case, neither should unequally distributed information nullify consent in the former.

\section{THE DRASTIC JURIDICAL TURN IN LESSIUS' ECONOMIC ETHICS}

The question is, of course, why Lessius holds so strictly to the narrow equality principle of commutative justice. First of all, one should not forget the increasing complexity and impersonality Lessius is confronted with in early-seventeenth-century business life. In an internationally frequented and busy place like the Antwerp exchange, for practical reasons it has become impossible to come to know of the situation and motives of any businessman - a sine qua non for a kind of moral reasoning trying to assess the morality of the economy in terms of the voluntary. The "objectivization" of moral evaluation was necessitated by the "objectivization" of the market itself. The attention towards the cause to the contract (causa vendendi), with the voluntary playing an important part, had to be replaced with a consideration of the impersonal mode of exchange (modus vendendi), with market circumstances occupying a pivotal role. A just price, then, should in the first place be a reflection of objective value determinants in the market, such as supply and demand, abundance or scarcity of money, and, last but not least, the particular mode of contracting (auction, sale on request, etc.). This way, economic analysis increasingly nestled itself as a vital prerequisite into the foundations of sound economic ethics.

A second factor explaining Lessius' rigid concentration on the requirements of commutative justice is to be found in the very evolution of Catholic moral theology. Under influence of the nominalistic idea of an ethics of obligation, the scholastic science of morals became ever more assimilated with legal thought, as opposed to the ethics of charity and happiness which can be witnessed in the patristic sources of late antiquity. ${ }^{57}$ This trend led to a most influential synthesis of ethics and law in the juridical-theological treatises On Justice and Right (De iustitia et iure) by Dominicus Sotus, Ludovicus Molina, and Leonardus Lessius amongst others ${ }^{58}$ - a fascinating reality urging us to reconsider the history of economic analysis in early modern times from the perspective of the history of legal thought in sixteenth- and

\footnotetext{
${ }^{55}$ De iustitia et iure 2, 21, 10.

${ }^{56}$ Jonsen and Toulmin 1988, pp. 251-252.

${ }^{57}$ Pinckaers 1985, pp. 254-255.

${ }^{58}$ Gordley 1992 [1991], pp. 69-111.
} 
seventeenth-century Europe. For is it a coincidence that historians of legal thought have pointed to Lessius as prefiguring Locke in his theory of property rights on the basis of personal labor, or as the direct source of inspiration for Grotius in his doctrine of subjective rights as well as in many crucial points of his contract theory, including the doctrine of error ${ }^{59}$ Let us illustrate the strong connection between Lessius' legal viewpoints and his economic ethics ideas by returning to "The Merchant of Rhodes." In our view, the divergence of opinion between Medina and Lessius with regard to the licitness of capitalizing on a dominant information position, in the end, can be reduced to a difference in contract doctrine, and in their standpoints on deception (dolus) and error (error), in particular.

According to Lessius, deception and error concern either substantial or accidental qualities of a contract. In addition, he asserts that deception may be caused either by the other party to the contract, a straw man, or indeed the deceived person. ${ }^{60}$ Thus, if the buyer presented in the case of "The Merchant of Rhodes" consents to the salepurchase agreement, the contract remains untainted, notwithstanding the buyer being deceived through unequal distribution of information. For, in Lessius' view, the buyer has been deceiving himself because of negligence and complacency. Through unflagging zeal, he could have expanded a web of intelligencers keeping him informed of the latest and future changes in market conditions-a remarkable opinion radically opposed to the idea of Medina and Summenhart that the deception is invincible as a vitiating circumstance, thus nullifying the agreement. ${ }^{61}$ Last but not least, in refuting Medina and Summenhart, Lessius repeatedly claims that the deception the buyer suffers from does not concern a substantial element of the contract, but rather an external circumstance. ${ }^{62}$ Therefore, the contract remains entirely valid, in spite of the buyer's self-deceit. ${ }^{63}$ It is clear, then, that as well as underlying his economic ethical statements, Lessius' juridical doctrine allows him to avoid a paternalistic attitude towards businessmen, and, more specifically, towards the buyer-hitherto usually regarded as the weaker party to the contract.

\section{“LA CONDITION COMMERCIALE": TO PLAY BUSINESS}

This brings us to the question of Lessius' conception of business - a third factor explaining his consistently sticking to the theory of the just price. In the opening chapter on buying and selling, Lessius defines commerce (negotiatio) as acquiring goods in order to make profits by selling them unchanged-adding immediately that such an act is indifferent from a moral point of view. ${ }^{64}$ On the positive side, the late scholastics were wholly convinced that doing business could well be regarded as

\footnotetext{
${ }^{59}$ See Carpintero Benítez 2003, p. 355; Haggenmacher 1997, p. 117; and Feenstra 1973, p. 386 respectively.

${ }^{60}$ De iustitia et iure $2,17,5,27$.

${ }^{61}$ De iustitia et iure $2,17,5,33$.

${ }^{62}$ De iustitia et iure 2, 17, 5, 34 .

${ }^{63}$ A similar reasoning might explain why Lessius connived at lying in "The Merchant of Rhodes." For, the lying concerns only an external circumstance of the contract, namely the future situation of the market, and not a substantial element such as price or commodity.

${ }^{64}$ De iustitia et iure 2, 21, 1, 4.
} 
a morally acceptable and socially useful profession. By externally transforming goods, that is trading them from one place to another, a merchant fulfilled the plan of God. For, in the beginning of creation, He had scattered all earthly riches across the globe with the intention that all nations be bound to enter into relation with each other through mutual exchange, thereby establishing a peaceful world community. Thus, for fulfilling such a salutary task, a merchant was allowed to receive a due compensation, or, put another way, it was licit for him to make profits.

Profits, of course, should not be obtained through fraud, conspiracy, or exorbitant price levels. Making profits should amount to the art of honestly taking advantage of fluctuations in the just price - an art demanding insight into various market conditions, and the shrewdness of finding and exploiting differences in prices. For, to a certain extent, the just price contains a margin. A clever merchant tries to buy his goods at the lowest just price (pretium pium), and sell them at the middle (pretium medium) or highest just price (pretium rigorosum). However, since success in commerce largely depends on good fortune, the art of making profits is a risky business. Bringing one's goods to the market a second too soon or too late might mean suffering a great loss. Getting a return on efforts, then, requires not letting a lucrative opportunity (occasio) slip away. For "la condition commerciale" 65 is to run the risk of failure just as much as to reap the fruits of fortune from time to time-a condition adequately described as "aleatoric" by Van Houdt. ${ }^{66}$ Consequently, the most important challenge for a businessman is to tame chance through experience and prudence. Despite the quirks of fate, he can try to detect a certain logic behind selfrepeating market phenomena, only to forestall them in the future. Thus, business becomes the art of predicting future events (ars coniectandi).

\section{LABOR, INDUSTRY, AND THE MECHANICS OF THE MARKET}

Lessius increasingly recognized that, to a certain degree, the market is logically functioning on the basis of laws and rules of its own. What is more, in the view of our Jesuit, a merchant who had gained insight into that specific logic should be allowed to reap the fruits of the profits he had made that way. It is clear that Lessius' perpetual appeal to the common estimation in assessing the morality of business consistently follows from his attempt to respect the efforts of a merchant trying to grasp the internal logic present in the market place. For, an insightful businessman (mercator prudens) plays the game of business by continually leaning on the fundamental legitimacy of the just price set by common estimation. The activity of a diligent merchant being wholly built on this fact, he would quite unjustifiably be made to look a fool, if, suddenly, a moral expert expected him to take into account the absolutely unpredictable voluntariness with which the other party enters into the sale-purchase contract. If the latter were the case, an industrious businessman could never gain from the efforts he had put in to master the logic of the market.

So, although at first glance Medina's solution of "The Merchant of Rhodes" looks much more justified than Lessius', on closer examination, it is discriminating. It

\footnotetext{
${ }^{65}$ Lessius literally talks about the "conditio mercatorum" in 2, 21, 4, 29.

${ }^{66}$ Van Houdt 1999b, p. 71.
} 
suggests that a careful businessman who painstakingly mounted a web of expertise and personal contacts to be able to predict the market conditions in a certain place at a certain time, ultimately cannot reap the fruits of that labor - a position going against any sense of logic. ${ }^{67}$ In point of fact, Medina ignores the basic principle of making licit profits: cleverly anticipating the differences in the just price set by common estimation. Lessius, on the contrary, fully recognizes business acumen. He affirms that not only should a surplus in knowledge not lead to losses-it should even be the source of making licit profits. Provided that other businessmen could have reached the same level of knowledge by making efforts, a merchant is allowed to exploit his carefully gathered information. This conceptual framework may explain Lessius' anti-paternalistic attitude towards the buyer. He who enters the market is expected to know the rules governing the game. As has been said before, a businessman is not supposed to be led by charity, even before the court of conscience. ${ }^{68}$

\section{BALANCING ON THE BORDERLINE}

To interpret the seemingly lax bias of Lessius' moral statements correctly, it is important not to forget that he is overseeing a market in which businessmen are professionals alternately buying and selling - a significant difference with medieval commercial practice, where buyers were simple people vulnerable to cunning sellers. Accordingly, the risk of abuse of power is either negligible, or not wholly invincible. This provides us with another explanation for Lessius' pitiless attitude towards the buyer in "The Merchant of Rhodes." Deception should be blamed on the merchant shallowly practising his trade in outright frivolity (levitas). ${ }^{69}$ Only if an industrious and assertive buyer cannot possibly bridge the information gap, should the seller unveil his knowledge. ${ }^{70}$ Now this is very unlikely in the case of "The Merchant of Rhodes." It suffices to recall Pufendorf's statement that from Antiquity onwards the inhabitants of Rhodes were considered very rich to see that the Rhodians could well have afforded to build up a better information network keeping them informed about future market conditions. ${ }^{71}$

Yet, whenever a merchant crosses the border of professional business life, he should beware of moral wickedness - a fact which becomes clear in Lessius' discussion of the just wage, where an agreement should be reached through a bargaining process, in the course of which neither party is allowed to eliminate his moral accountability. ${ }^{72}$ Similarly, upon seeing that through simplicity (simplicitas), as opposed to frivolity (levitas), a buyer or seller is likely to become an easy prey to his shrewdness, a businessman should shoulder responsibility for saving him. ${ }^{73}$ Standing up for the

\footnotetext{
${ }^{67}$ One should not forget that, even if someone has painfully gathered information, he still runs the risk of having obtained false or misleading information: $2,12,18,130$.

${ }^{68}$ Cf. supra "Self-interest, lying, and charity."

${ }^{69}$ See, for instance De iustitia et iure 2, 21, 5, 43; 10, 79 and 11, 91.

${ }^{70}$ Similarly, a seller is not obliged to tell about the defects of his goods unconditionally. For Lessius' discussion of sale-purchase involving defective merchandise, see De iustitia et iure 2, 21, 11.

${ }^{71}$ See above "After Lessius. Catholic and Protestant traditions."

${ }^{72}$ See the interesting study by Noell 2001, pp. 481-485.

${ }^{73}$ Langholm 1998, p. 116.
} 
poor and weak man throughout his discourse on sale-purchase, Lessius proves himself to remain a true inheritor of the scholastic legacy in economic thought. ${ }^{74}$ On the other hand, one cannot deny that his permissiveness regarding the interactions of professionals amongst one another is far-reaching. In his view, it seems a foregone conclusion that a diligent businessman is allowed to overreach the frivolous. Molina, by contrast, while equally consistently extracting the consequences of the narrow principle of equality, still unambiguously stood by the common good. Thus, on no account was a merchant allowed to cash in his private knowledge of a law, by definition destined to the welfare of the community. Though giving in to profit-seeking as a necessary incentive to commerce, Molina did not consent to business activities coming at the expense of one's colleague.

It remains to be seen whether Lessius did not let the salutary art of economics degenerate into unbridled mercenarism in the hands of the shrewd businessman-the former being the basic principle of scholastic economics. ${ }^{75}$ One cannot escape the impression that the merchant he has in view does not care about the value in use of the goods he buys, but merely concentrates on their value in exchange. Among his peers, a businessman is allowed to rely on blind economic forces, abstracting from personal moral responsibility towards fellow merchants - the latter attitude rightly being considered the cornerstone of the scholastic paradigm. ${ }^{76}$ In a few remarkable passages in his detailed discussion of "The Merchant of Rhodes," the common good-albeit reluctantly-gives way to the charms of the private good. The universe his merchant is living in looks suspiciously similar to that of the homo oeconomicus, unremittingly striving at profit maximization, and making information a lethal weapon in competing with his fellow individuals.

Is it late scholasticism itself rather than Protestantism or the rebirth of genuine Roman law which heralds in the end of the "ethics of fraternity" believed to underlie the scholastic paradigm in economic thought? In any event, though he was far from developing any general theory of economic growth, Lessius set free the agents necessary to undertake such a process of material wealth creation by defending before the court of conscience industrious merchants striving to make profits from their insight into the laws of the marketplace.

\section{REFERENCES}

Baeck, Louis. 1994. The Mediterranean tradition in economic thought. Routledge history of economic thought series. London and New York: Routledge.

Belda, Francisco. 1963. Etica de la creación de créditos según la doctrina de Molina, Lesio y Lugo. Excerpta ex dissertatione ad Lauream in Facultate Philosophica Pontificiae Universitatis Gregorianae. Madrid: Sucs. de Rivadeneyra.

Beutels, Robert. 1987. Leonardus Lessius 1554-1623. Portret van een zuidnederlandse laat-scholastieke econoom. Een bio-bibliografisch essay. Wommelgem: Den Gulden Engel.

Carpintero, Benítez. 2003. "Los escolásticos españoles en los inicios del liberalismo político y jurídico." Revista de Estudios Histórico-Jurídicos 25: 341-373.

\footnotetext{
${ }^{74}$ De iustitia et iure $2,21,9,76 ; 11,93 ; 16,131 ; 21,145$; and $21,151$.

${ }^{75}$ See Gómez Camacho 1998a, pp. 155-167.

${ }^{76}$ Gómez Camacho 1998b, p. 528.
} 
Chafuen, Alejandro A. 2003. Faith and liberty. The economic thought of the late scholastics. Studies in ethics and economics. Lanham-Boulder-New York-Oxford: Lexington.

Clavero, Bartolomé. 1991. Antidora. Antropología católica de la economía moderna. Per la storia del pensiero giuridico moderno, 39. Milan: Giuffrè.

Decock, Wim. 2005. Breaking the limits. De "homo oeconomicus" ontketend in Lessius' denken over markt en prijs? Leuven [unpublished master's thesis].

Decock, Wim. 2006. "Leonardus Lessius en 'De koopman van Rhodes.' Een schakelpunt in het denken over economie en ethiek." De zeventiende eeuw 22(2): 247-261.

Decock, Wim. 2007. "Leonardus Lessius on Buying and Selling (1605). Translation and Introduction." Journal of Markets and Morality 10(2): 433-516.

Decock, Wim. 2008. "L'usure face au marché: Lessius (1554-1623) et l'escompte des lettres obligataires." In Anne Girollet, ed., Le droit, les affaires et l'argent. Célébration du bicentenaire du code de commerce, MSHDB, 65. Dijon.

De-Juan, Oscar and Monsalve Fabio. 2006. "Morally ruled behaviour: the neglected contribution of scholasticism." The European Journal of the History of Economic Thought 13(1): 99-112.

De Roover, Raymond. 1969. Leonardus Lessius als economist. De economische leerstellingen van de latere scholastiek in de Zuidelijke Nederlanden. Mededelingen van de Koninklijke Vlaamse Academie voor Wetenschappen, Letteren en Schone Kunsten van België, Klasse der Letteren, 31.1. Brussels: Paleis der Academiën.

Feenstra, Robert. 1973. "L'influence de la Scolastique espagnole sur Grotius en droit privé: quelques expériences dans des questions de fond et de forme, concernant notamment les doctrines de l'erreur et de l'enrichissement sans cause." In Paolo Grossi, ed., La seconda scolastica nella formazione del diritto privato moderno. Atti del Incontro di studio (Firenze, 16-19 ottobre 1972), Per la storia del pensiero giuridico moderno 1. Milan: Giuffrè.

Gómez Camacho, Francisco. 1981. Luiśs de Molina. La teoría del justo precio. Edición preparada por Francisco Gómez Camacho. Madrid: Editora Nacional.

Gómez Camacho, Francisco. 1998a. Economía y filosofía moral: la formación del pensamiento económico europeo en la Escolástica española. Madrid: Editorial Síntesis.

Gómez Camacho, Francisco. 1998b. "Later scholastics: Spanish economic thought in the 16th and 17th centuries." In Todd S. Lowry and Barry Gordon, eds., Ancient and medieval economic ideas and concepts of social justice. Leiden: Brill Publishers.

Gordley, James. 1992 [1991]. The philosophical origins of modern contract doctrine. Clarendon Law Series. Oxford and New York: Oxford University Press.

Gordon, Barry. 1975. Economic Analysis before Adam Smith. Hesiod to Lessius. London: Macmillan.

Grice-Hutchinson, Marjorie. 1952. The School of Salamanca. Readings in Spanish Monetary Theory. 1544-1605. Oxford: Clarendon Press.

Haggenmacher, Peter. 1997. "Droits subjectifs et système juridique chez Grotius." In L. Foisneau, ed., Politique, droit et théologie chez Bodin, Grotius et Hobbes. Paris: Editions Kimé.

Hamouda, Omar and Betsy B. Price. 1997. "The justice of the just price." The European Journal of the History of Economic Thought 4(2): 191-216.

Hénaff, Marcel. 2003. "Religious ethics, gift exchange and capitalism." Archives européennes de sociologie 44(3): 293-324.

Jonsen, Albert R. and Toulmin Stephen. 1988. The abuse of casuistry. A history of moral reasoning. Berkeley-Los Angeles-London: University of California Press.

Koslowski, Peter. 1991. "Ethische Oekonomie und theologische Deutung der Gesamtwirklichkeit in der Summa Theologiae des Thomas von Aquin.” In Peter Koslowski et al., eds., Oekonomie, Politik und Ethik in Thomas von Aquins 'Summa Theologiae.' Vademecum zu einem Klassiker der Wirtschaftsethik. Klassiker der Nationalökonomie. Düsseldorf: Handelsblatt.

Langholm, Odd Inge. 1979. Price and value in the Aristotelian tradition. A study in scholastic economic sources. Bergen: Universitetsforlaget. 
Langholm, Odd Inge. 1998. The legacy of scholasticism in economic thought. Antecedents of choice and power. Historical perspectives on modern economics. Cambridge: Cambridge University Press.

Lapidus, André. 1994. "Norm, virtue and information: the just price and individual behaviour in Thomas Aquinas' Summa Theologiae." The European Journal of the History of Economic Thought 1(3): 435-473.

Noell, Edd S. 2001. "In pursuit of the just wage: a comparison of reformation and counter-reformation economic thought." Journal of the History of Economic Thought 23(4): 467-489.

Noonan, John T. 1957. The scholastic analysis of usury. Cambridge Mass.: Harvard University Press.

Pinckaers, Servais. 1985. Les sources de la morale chrétienne. Sa méthode, son contenu, son histoire. Études d'éthique chrétienne, 14. Fribourg: Éditions universitaires.

Schefold, Bertram, ed. 1999. Leonardus Lessius' De iustitia et iure. Vademecum zu einem Klassiker der spätscholastischen Wirtschaftsanalyse. Klassiker der Nationalökonomie. Düsseldorf: Verlag Wirtschaft und Finanzen der Verlagsgruppe Handelsblatt.

Schumpeter, Joseph A. 1972 [1954]. History of economic analysis. Edited from manuscript by Elizabeth Boody Schumpeter. London: Allen and Unwin.

Spies, Marijke. 1990. "De koopman van Rhodes. Over de schakelpunten van economie en cultuur." De zeventiende eeuw 6(1): 166-174.

Stone, Martin W. F. and Van Houdt Toon. 1999. "Probabilism and its methods: Leonardus Lessius and his contribution to the development of Jesuit casuistry." Ephemerides Theologicae Lovanienses 75: 359-394.

Stone, Martin W. F. 2004. "Scrupulosity, probabilism, and conscience. The origins of the debate in early modern scholasticism." In Harald Braun and Edward Vallance, eds., Contexts of conscience in early modern Europe, 1500-1700. London: Palgrave.

Van Houdt, Toon. 1998a. Leonardus Lessius over lening, intrest en woeker. De iustitia et iure, lib. 2, cap. 20. Editie, vertaling en studie, Verhandelingen van de Koninklijke Academie voor Wetenschappen, Letteren en Schone Kunsten van België. Klasse der Letteren, 162. Brussels: Paleis der Academiën.

Van Houdt, Toon. 1998b. "Tradition and renewal in late scholastic economic thought: the case of Leonardus Lessius (1554-1623)." The Journal of Medieval and Early Modern Studies 28(1): 51-73.

Van Houdt, Toon. 1998c. “'Lack of money': a reappraisal of Lessius' contribution to the scholastic analysis of money-lending and interest-taking." The European Journal of the History of Economic Thought 5(1): 1-35.

Van Houdt, Toon. 1998d. "De economische ethiek van de Zuid-Nederlandse jezuïet Leonardus Lessius (1554-1623): een geval van jezuïtisme?" De zeventiende eeuw 14(1): 27-37.

Van Houdt, Toon. 1999a. "The economics of art in early modern times: some humanist and scholastic approaches." In Neil De Marchi and Craufurd D. Goodwin, eds., Economic Engagements with Art. Annual Supplement to Volume 31, History of Political Economy. Durham-London: Duke University Press.

Van Houdt, Toon. 1999b. "Spelen om geld. Gokken, wedden en loten in het moraaltheologische discours in de Zuidelijke Nederlanden (einde zestiende—begin zeventiende eeuw)." De zeventiende eeuw 15(1): 61-73.

Van Houdt, Toon. 2000. "Just pricing and profit making in late scholastic economic thought." In Dirk Sacré and Gilbert Tournoy, eds., Myricae. Essays on Neo-Latin literature in honour of Jozef IJsewijn. Supplementa Humanistica Lovaniensia, 16. Leuven: Leuven University Press.

Van Houdt, Toon and Decock Wim. 2005. Leonardus Lessius: traditie en vernieuwing. Antwerpen: vzw Marie Belpaire.

Vereecke, Louis. 1991. "Le probabilisme." Le Supplément. Revue d'Ethique et Théologie Morale 177: 23-31.

Vivenza, Gloria. 2001. "The 'Northern' Cicero: on the fortuna of the De Officiis in central Europe." Mésogeios 13-14: 201-27.

Vivenza, Gloria. 2004. "Renaissance Cicero. The 'economic' virtues of De officiis I, 22 in some sixteenth century commentaries." The European Journal of the History of Economic Thought 11(4): 507-523. 
Weber, Wilhelm. 1959. Wirtschaftsethik am Vorabend des Liberalismus. Höhepunkt und Abschluss der scholastischen Wirtschaftsbetrachtung durch Ludwig Molina S.J. (1535-1600). Schriften des Instituts für christliche Sozialwissenschaften an der Westfälischen Wilhelms-Universität Münster, 13. Münster.

Whitman, James. 1996. "The moral menace of Roman law and the making of commerce: some Dutch evidence." Yale Law Journal 105(7): 1841-1889.

Young, Jeffrey T. and Barry Gordon. 1992. "Economic justice in the natural law tradition: Thomas Aquinas to Francis Hutcheson." Journal of the History of Economic Thought 14: 1-17.

\section{PRIMARY SOURCES CITED}

Amesius, Guilielmus, De conscientia et ejus iure vel casibus libri quinque (Amstelodami, ca. 1650) [1632].

Aragonensis, Petrus, De iustitia et iure (Venetiis, 1595) [Salmanticae, 1590].

Cicero, Marcus Tullius, De Officiis. In Cicéron, Les devoirs. Livres II et III. Texte établi et traduit par Maurice Testard, Collection des Universités de France, Paris, 1970.

Grotius, Hugo, De iure belli ac pacis (Amsterdami, 1631) [Parisii, 1625].

Lessius, Leonardus, De iustitia et iure (Antverpiae, 1621) [Lovanii, 1605].

Lessius, Leonardus, Variorum casuum conscientiae resolutiones. In I. Wijns, ed., L. Lessii opera posthuma (Lovanii, 1645).

Lessius, Leonardus, De beatitudine et actibus humanis praelectiones. In I. Wijns, ed., L. Lessii opera posthuma (Lovanii, 1645).

Ligorio, Alphonsus de, Theologia moralis. In Opera moralia Sancti Alphonsi Mariae de Ligorio. Theologia moralis. Editio nova cura et studio Leonardi Gaudé, tom. 2 (Romae, 1907) [Neapoli, 1748]

Medina, Ioannes, De poentitentia, restitutione et contractibus (Ingolstadii, 1581) [Salmanticae, 1550].

Molina, Ludovicus, De iustitia et iure (Moguntiae 1659 [Cuencae, 1597]).

Pufendorf, Samuel, De jure naturae et gentium. In F. Böhling, ed., Samuel Pufendorf. De jure naturae et gentium. Zweiter Teil: Text (Liber quintus_Liber octavus), in the series of W. Schmidt-Biggemann, ed., Samuel Pufendorf. Gesammelte Werke, Band 4.2 (Berlin, Akademie Verlag, 1998)].

Summenhart, Conradus, De contractibus (Hagenau, 1513 [1500]). 